\title{
EXPLORING REFUGEE AGENCY THROUGH DOCUMENTARY PRODUCTION OF RESETTLING KAREN IN AUSTRALIA
}

\author{
Manoch Chummuangpak
}

Dhurakij Pundit University, Thailand

\begin{abstract}
This article analyses a documentary video produced by a Karen refugee who now has resettled in Australia, revealing the agency of the Karen in relation to the accessibility of mediamaking equipment and know-how. The documentary titled New Land, New Life: Karen Youth in Australia (2013) is directed by Moewin Tunkin, who fled from his home country, Myanmar due to prolonged civil unrest. Like most other Karen refugees in third countries, he found that while resettlement has much improved the lives of the Karen, it also has brought about many challenges. As a media enthusiast, he produced the 19-minute documentary with an aim to present the situation of Australian-Karen residents. Applying the concept "authorial voice" from a documentary studies theory, this article shows how the media message is constructed and legitimized through linguistic and visual presentation techniques. It reinforces the notion of refugee agency suggesting that refugees or displaced persons cannot be oversimplified as 'defenceless victims' or 'mute victims'. In this case, the refugee producer has strived to become a proactive social actor by committing himself to media-making practice and creating an advocacy tool to raise awareness of the situation of the Karen, notably regarding insufficient support from the government and host society.
\end{abstract}

Keywords: refugee media; refugee agency; documentary; resettlement

Introduction: The migration of the ethnic Karen and their media-making practices

In Myanmar (also known as Burma), there are many ethnic groups divided by distinct languages, cultural patterns and political aspirations. The country has a population of around 55 million and two thirds of the population are the ethnic Burman or Bamar. The Karen people are one of the Myanmar's largest minority groups (Fuertes, 2010, p.20). Since the 1980s, prolonged ethnic conflict and civil unrest as well as harsh economic conditions in the country have forced a large number of the ethnic Karen to flee their home country for sanctuary.

Thawnghmung (2012, p.xvii) estimates that 500,000 Karen refugees or more have crossed borders to live in other countries, notably the constant flow of the Karen to refugee camps along the Thai western border and more recently, the emergence of Karen communities in countries of resettlement. Amidst the outflows of the Karen people, many elite and ordinary Karen alike have tried to maintain their Karen identity and keep their dispersed co-nationals connected (Green \& Lockley, 2012; Harkins, 2012; Rangkla, 2014). In particular, the displaced Karen are concerned about preserving their heritage in the form of language, traditions and cultural artefacts and importantly, hope to convey this Karen heritage to their descendants who may not have a chance to see what the Karen homeland is like.

Nowadays, people's social lives and media practices are hard to separate, not only in dominant but also subordinate communities like people who are displaced from their countries of origin. As Bailey, Georgiou \& Harindranath (2007, p.6( suggest, media engagement can play a role in helping "forge feelings of 'belonging' and 'bridging', creating mediated, symbolic spaces for political expression, senses of inclusion or/and exclusion, and hybrid identity articulations which transcend the binary of 'homeland' and 'new land'.' 
Like most people in modern society, media-related activities, especially media production have become popular among many Karen refugees who have resettled in developed countries. This is significantly related to the expansion of electronic and digital media in the past several decades. Karen refugee media are not only increasing in quantity, but also in the variety of media forms and content. Despite difficult and poor living conditions as well as the consequences incurred by their subordinate status, the refugee media creators have tried to learn and master advanced media and communication technologies and have produced a range of media outlets. Many of them have taken part in the media-making practices in order to preserve their cultural identity and present their own stories and voice their concerns resulting from displacement and resettlement situations.

Media produced by Karen refugees now are varied, including, for instance, newsletters and news websites produced by Karen refugee organisations; music and video CDs and DVDs produced by professional and amateur Karen singers and musicians in various countries (particularly Thailand, Australia, Sweden, Norway and the United States); community media projects in some resettlement countries; and online social media that are used by Karen individuals as well as formal and informal Karen-based groups to share stories, photos and videos through their transnational networks. In the age of digital media and the internet, the line between media producers and consumers has also become blurred. There is a growing number of amateur Karen media producers or media enthusiasts. Notably, the past few years have seen many young Karen refugees involved in the creation of Karen media like music videos, making use of equipment such as computers, digital video cameras, sound recording and video editing software that are now more affordable and easy to use.

According to Matsaganis, Katz \& Ball-Rokeach (2011, p.76), one of the important roles of media produced by marginalised groups is to stand for their communities or "to present themselves in their own words". They further point out that although we should not assume that mainstream media are insensitive to issues affecting ethnic and minority groups, the opportunities to present their own stories in their own words can empower people who are marginalised by dominant societies. As they put it (p.77),

"the chance to tell a story about one's own people, in one's own words, is an important part of creating and maintaining an ethnic identity. Independent media, created by members of an ethnic group for that group, create spaces for developing a sense of community, sharing common events and experiences, and arguing for common causes."

This paper analyses a documentary video produced by a Karen refugee who now has resettled in Australia, which is extracted from my PhD research titled "Media Practices, Displacement and Transnationalism: Media of and by Karen Refugees from Burma". It reveals the agency of the Karen in relation to the accessibility of mediamaking equipment and know-how. This examination will shine more light on the relationship between media creation and forced migration and settlement which has not yet received significant attention in the existing literature.

\section{New Land, New Life: Karen Youth in Australia, a refugee documentary project}

The Karen in the state of Victoria, Australia are one of the earliest emerging Karen communities in resettlement countries. The emergence of resettling Karen communities has resulted from refugee resettlement schemes provided by the United Nations High Commissioner for Refugees (UNHCR) since the mid-2000s. This is because refugees on the Thai-Myanmar border represent the largest protracted refugee situation in East Asia (Banki \& Lang, 2008, p.59).

The numbers of Karen refugees in Victoria have constantly increased over the past decade (since 2007 in particular). It is estimated that there are 2,500-3,000 Karen residents in Victoria, out of a total of 7,000 in Australia. According to Bodde (2011, p.1), while resettlement has much improved the lives of these Australian Karen residents, it also leads to many challenges for them. Some examples are an inflexible education model for young refugees, socialising and health care, cultural and language barriers and financial difficulties. These 
hardships are common among Karen communities in other resettlement countries as well as other resettling refugee communities from Myanmar (Power \& Pratt, 2012; Swe, 2013; Thawnghmung, 2012).

The 19-minute documentary titled New Land, New Life: Karen Youth in Australia was directed by Moewin Tunkin, a Karen refugee enthusiast resettling in Melbourne in the state of Victoria. After completing a media production program at a TAFE (Technical and Further Education) college in 2011, Moewin had an opportunity to make the short documentary which was supported by the Australian Karen Foundation (AKF). The AKF was established in 2007 by several local Australians who have primarily contacted Karen communities through a Christian network and concentrates on educational and leadership development projects. The organisation, which took responsibility for seeking funding for the project, proposes that this documentary might be used as an advocacy tool to raise awareness of the situation of the Karen in Australia, notably regarding insufficient support from the government and host communities. I have known Moewin since late 2011 when I started to conduct a research on media practices of the displaced Karen in Australia. I volunteered to take part in this documentary project as one of the project advisors between 2012 and 2013.

The documentary focuses on the story of the struggle of Australian Karen youth when integrating into the new country. It especially highlights several key issues affecting the resettlement experiences of the young Karen, for example, difficulties in studying in the mainstream educational system and in finding satisfying jobs. These issues are illustrated through three main presenters, one male, Lay Wah, and two females, Delta and Mayre.

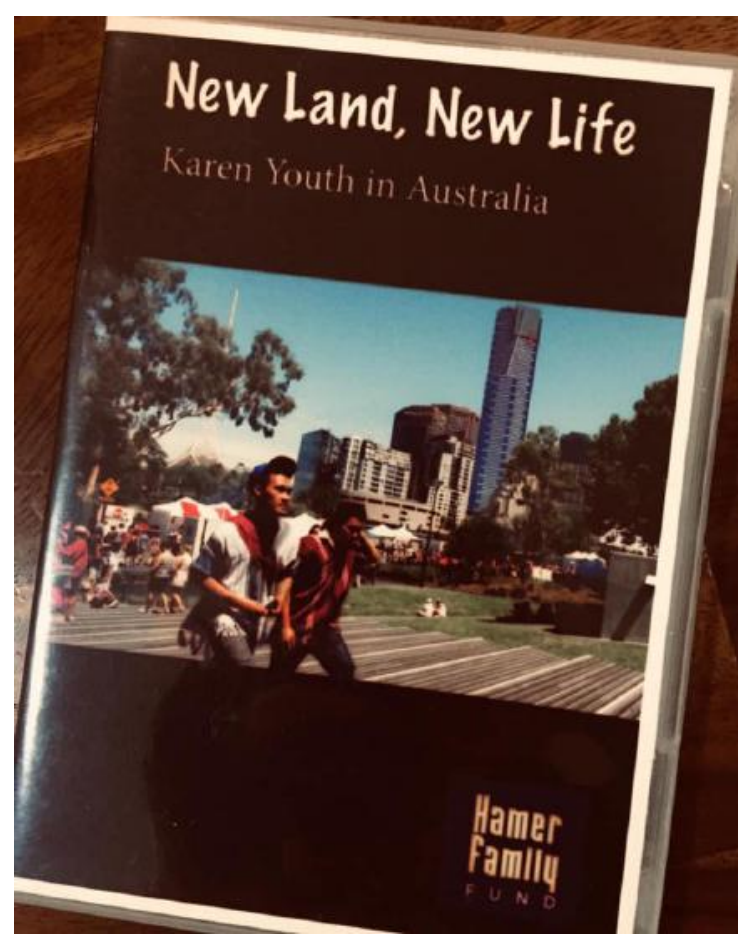

Figure 1:DVD cover of the documentary New Land, New Life showing two young Karen refugees in Karen traditional shirts walking in a modern city 


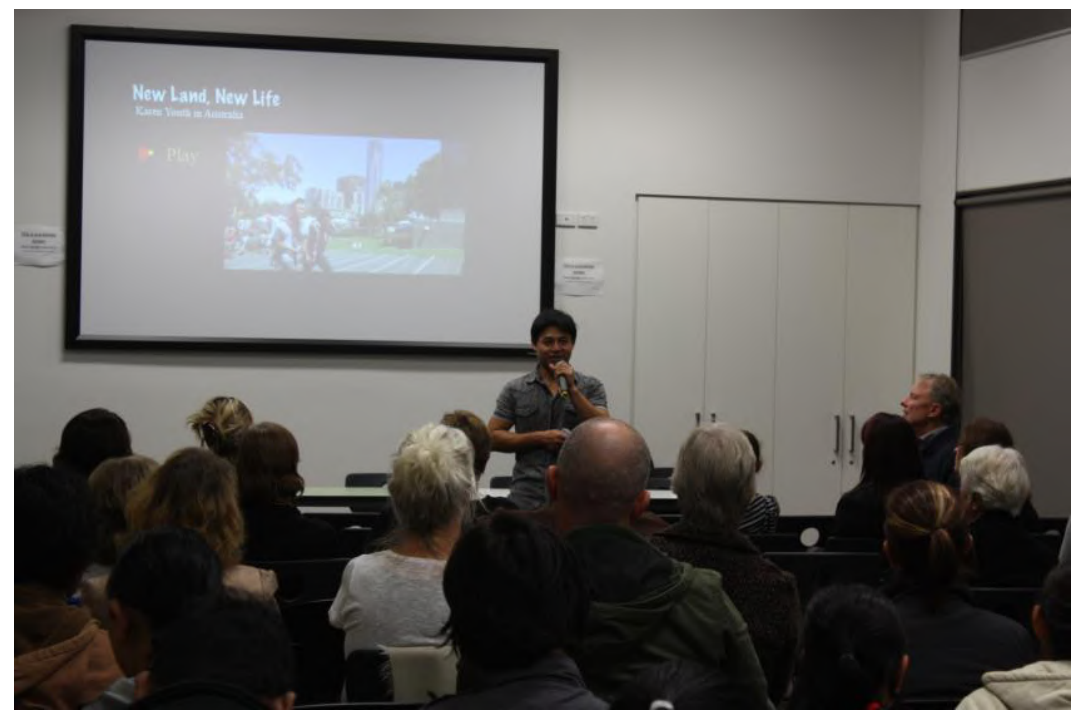

Figure 2 :The director introducing his documentary project at a screening event in Melbourne and receiving positive feedback

The documentary was screened at several community events in Melbourne in early 2013 and received quite positive feedback. Some of the audiences who worked for local government, community-based or religiousbased organisations, for example, commented that watching the documentary allowed them to appreciate and understand more about the problems that young Karen have faced. Besides public screening, the documentary also has been distributed in DVD, mainly through the AKF networks. The director got supportive responses from those who bought the DVDs and said that they were inspired by the story of the Karen youth presented in documentary New Land, New Life.

\section{The documentary's authorial voice}

Applying the concept "authorial voice" from a documentary studies theory, this section will reveal how the message in the refugee documentary is constructed and legitimized through linguistic and visual presentation techniques. Documentary scholars like Austin and de Jung (2008) and Ellis (2012), among others, regard the documentary as a set of events or evidence that are purposively and strategically selected and then reorganised by the producers whose arguments and viewpoints are expressed through the media text. Used as an analytical concept, authorial voice deals with the matter of 'how the message is constructed', rather than 'how true the message is'. More significantly, authorial voice entails the examination of ways in which the narrative and cinematic apparatus is used in creative work to convey the producers' key messages or arguments. In this instance, it discloses the creative practices and capabilities of the media producers.

In a similar vein, Chapman (2009, p.93) suggests that "authorial voice refers to what the documentary is saying - what sort of comment it is making on the world ... a power of a documentary resides in the potential challenge that its message or argument may make to accepted views." Put simply, the more documentaries can make their authorial voice legitimate, the more the purposes to which the documentaries want to serve tend to be met. Chapman (2009, pp.93-94) further points out that the conveyance of authorial voice relies on "authorial intention and skills (both aesthetic and technical)" and "involves both linguistic and visual representations". She puts the issue differently (2007, p.12):

"Authorial voice is firstly about original intent. The original concept will dictate the documentary material that is chosen, structured, fashioned and packaged for presentation. The filmmaker selects a technique or number of different techniques that will act as a vehicle for authorial voice."

By taking a closer look at the documentary narrative, I suggest that this Karen media product appears to convey its key message to its potential viewers in an effective way by using a range of narrative devices and cinematic 
techniques. In particular, the way in which New Land, New Life constructs its authorial voice manifests the aesthetic and technical skills of its director. Notably, the authorial voice is communicated through the dramatisation of factual reality, which is a widely used technique in documentary production worldwide (Bondebjerg, 2014, p.16). As will be illustrated, the dramatisation that emerges from the selected interview materials, voiceover narration and editing, for example, plays a prominent role in consolidating the message that the documentary attempts to convey to its audiences.

\section{Part 1: the tense past}

The documentary begins its narrative in an emotive way. Before viewers can see anything, they are allowed only to hear the sound of gunshots. After a few seconds pass, the image of fighting fades in slowly. The camera is shaking all the time and the image quality is quite low, which suggests that these fighting shots are real footage. After giving a very tense experience by letting viewers witness the situation in the battlefield, the documentary uses white-colour text appearing on a plain dark background to link the fighting scene with the Karen struggle for self-determination, together with slow and intense background music.

For the last sixty-two years the country of Burma has been in a civil war with the Karen people.

The Karen are one of the largest ethnic groups in Burma with a population around 7 million.

The Karen have been attacked and oppressed by the Burmese military dictatorship, experiencing rape, torture and killing.

Simultaneously, several shots of a group of adults and children desperately walking in line in a jungle, followed by a woman crying over a dead body, are inserted. Audiences also witness another group of Karen in the jungle. It is raining so it looks harder for them to walk. From the text provided previously, it now becomes clear to viewers that the people are fleeing from Burmese soldiers. A voiceover commentary then is present while a series of shots portraying the hardship of the escape continues. From the accent of the male narrator, it is obvious that he is not a native English speaker. The pronoun 'we' he uses reveals his Karen identity. He also discloses that he himself is the director of this documentary, which in turn could make audiences believe that he should know the story he is telling very well. The Karen narrator says:

"This is how we fled from the Burmese Army attacks. I remember we didn't have enough food. And some people got sick and we were hiding and afraid. I made this film about the lives of three young Karen people ... their joy and struggle both in the refugee camp and in Australia."

After that, the documentary takes viewers to Mae La refugee camp (informed by a text caption) and then the first presenter, Lay Wah is introduced. He introduces himself to viewers and so do the other two presenters, Delta and Mayre. Each of them gives similar brief details about him/herself including name, the place they were born (Burma or the border) and how long they lived as refugees in Thailand. They also recall their experience of living in the camp. Mayre, for instance, says:

"When I first arrived there [Mae La camp], I felt so lonely and sad because I got no relatives and I had nowhere to go ... No opportunity to study when we finish Year 10 and no opportunity to go outside and work ... no freedom to go anywhere."

For Lay Wah, "life in the camp was not easy. We cannot go outside and we were locked like animals". This recollection scene is constructed to underline the hardship of refugee life by using some narrative devices. Before Lay Wah says that refugees were locked in the confined camp, for example, a shot of a refugee girl behind a barbed wire fence is intentionally inserted. Also, a seemingly insignificant story told by Lay Wah is selected to present in this scene. Lay Wah tells a story about the rooster he raised in the camp: 
"My grandfather gave [me] a baby chicken. I looked after it until it grew big enough. It was a very good fighting rooster. But one day when I was away, my father cooked it for visitors. I felt very sad and cried very loud. I loved my rooster very much and it was my friend. So I never forgot this memory."

Considering the director's intention, this 'cooked rooster' story clearly is not compulsory. It however is included in the documentary because it can give audiences an insight into the life of the Karen in refugee camps and helps to underline that most refugees have nothing. When visitors come to their houses, they cannot even give the visitors the hospitality which among the Karen is considered appropriate. According to Abbott (2008, pp.2223), there are two types of events used to construct a story, including constituent events and supplementary events. While constituent events "are necessary for the story to be the story it is", supplementary events "can be removed and the story will still be recognisably the story that it is". The presence of the 'cooked rooster' event fits a description underscored by Abbott that "supplementary events can be very important for the meaning and overall impact of the narrative".

Clearly, this first sequence of the documentary provides viewers the representation of the loss, collectively and individually, of the displaced Karen and especially Karen refugees in the confined camp. In this way, viewers, to a greater or lesser degree, would feel sympathy for the Karen and also appreciate if they are able to seek a better and more secure life.

\section{Part 2: the new land and many challenges}

The second sequence, which is the main part of New Land, New Life, begins with several shots of modern streets and city life with which local Australians are familiar (e.g., tram rails and train stations). Upbeat music suggests a more relaxed atmosphere, in marked contrast to the previous sequence presenting the refugee life on the border. The three young Karen inform the audience about the beginning of their lives in their new home. In this part, interviews play a key role in letting the audience gain an understanding of the newcomers' experience. Firstly, the three presenters point out the difficulties they faced when they first arrived. Lay Wah says:

"I came to Australia in December 2006. When I first arrived in Australia, I felt very strange because I have never seen a place like this before. And I felt very sad because I didn't see many Karen people here. And I didn't like it here."

Mayre then explains that "when I first arrived [in] Australia, I felt so scared and nervous. And living in Australia, I found [it] not easy to settle down as my homeland because of language difficulty". Delta likewise reveals that "I did find making new friends hard when I first came because of my lack of English". Yet, the presenters also speak about good things they feel about living in the new country (e.g., opportunities to study and work, good transportation and heath care) which help to balance the documentary's representation. Considering that providing balance is an important narrative device that builds audience trust, which can play an integral part in justifying a documentary's arguments (Chapman, 2007, p.58), this scene and other following scenes show that the director is aware of the significance of this narrative device.

Viewers then are given a chance to witness what the three presenters are doing at the present time, about 4-7 years after resettlement. All of them are struggling somewhat with integrating into the new society (which is no doubt why these presenters were selected by the documentary maker), but have quite different paths. Delta says that she is studying in year 11 and has been awarded a humanitarian scholarship. As she puts it, "I consider myself very fortunate for that". Nonetheless, she later reveals her concern that "my biggest challenge right now is to be finishing VCE [Victorian Certificate of Education] and do really good at it. So I can get into medicine".

Lay Wah explains how employment has become a big challenge for him. He finished a carpentry course some months ago but could not find an apprenticeship. As he says, "I applied to many places, but until now I didn't get it". In this scene, a combination of narrative techniques is employed to underline the difficulty in finding a job even though he has a paper qualification. A reconstruction event is filmed and inserted to visualise Lay Wah's disappointment and confusion. The reconstruction shots show the young Karen hurriedly walking in front 
of several job agencies and his confused search for something on his computer at home. Also, background music with a repetitive melodic structure plays an integral part in highlighting the presenter's confusion. While seeing what Lay Wah is facing, the audience have affirmed by his own words that "it is really hard to get a job in Australia. I think it is my biggest challenge".

Following Lay Wah, Mayre also convinces the audience of how difficult the life of young Karen in Australia is. She says that "the biggest challenge living in Australia is speaking English language. Because of my poor English, I wanted to go to university but I can only choose to work".

After that, viewers witness a different side of the young Karen. In particular, the presenters show that despite the challenges they have to face, they are aware that they have good opportunities and a better livelihood in this new country. As such, they would like to contribute to Karen society and disadvantaged Karen. Lay Wah says that "one day I think I can help my people in a way [from] what I learn in Australia". Mayre reveals her aspiration that "in the future I want to be a missionary or social worker". Delta likewise explains that "I see myself as a Karen person who makes a difference for the Karen people in the future" (some viewers may be delighted by associating this aspiration of Delta with her intention to study medicine). Again, background music is effectively used to underline the hope and commitment of the young Karen.

After about 5 minutes focusing on the views, experiences and motivations of the three main presenters, the documentary convinces its audience of what the young people recently revealed by using several 'experts' or reliable interviewees (a common and influential technique found in many mainstream documentaries). First, the audience sees a Karen community leader who relates:

"Young people, they come to Australia with their dream and they have a very high expectation for their future. So when they come here, they study and they work hard. They are very motivated. It is a good thing. But resettlement is not easy as ... you know some people imagined. There're a lot of difficulty and challenge ahead of you, ahead of us. So the young people when they come here, because of language problem, it is a challenge for them to study. Some parents, they are doing very well to support their children. But some parents, they have difficulty to support their children even they want it very much. Because they themselves struggle and have difficulty with resettlement." [several shots of Karen adults studying nervously in an English class are inserted]

After that, another 'expert' interviewee, a local Australian working as the co-ordinator of Foundation House (an Australian NGO) is presented. She elaborates:

"Young Karen people arrive here with many talents and many experiences [a shot of young Karen doing a hiphop dance is inserted] ... They also arrive with many hopes and dreams, particularly in relation to education for their future. One of the challenges for them educationally is to study in English. And the second challenge is to study in an education system that operates in a different way from the one that they have been used to in the camps or inside Burma. And many of them over time find that difficult and lose confidence, educationally. I don't think they are able to feel that their talents are valued and they are able to achieve what they hope and dream that they could achieve."

It is apparent that these two interviewees are used in a potent way to convey the argument of the documentary. Their relatively long interview scene (about 1 minute each) plays a role in underlining the constraints imposed on the three Karen presenters and other Australian Karen youth in general. Most importantly, the two interviewees convince viewers that those constraints, to a certain extent, result from factors that the displaced Karen cannot control (e.g., language barrier and education system). Nonetheless, the young people try very hard to cope with the problems and to integrate into the host country. At this point, many viewers may not only sympathise with the young Karen, but also appreciate their strengths and endeavour.

After that, a voiceover commentary is presented to shed light on the situation of Karen youth in Australia. The Karen narrator details that "Karen young people aged around twenty to twenty-five find study hard, especially English, so many choose apprenticeship training at TAFE. When they finish training such as carpentry or 
mechanics, usually they cannot find apprenticeship jobs". Simultaneously, the documentary provides a glimpse of the workplace where several young Karen work, followed by a comment from the co-ordinator of Foundation House:

"There are also many reasons why young people choose to work from an early age. Families often try to resettle and establish themselves in Australia. And sometimes they really want the income that the young people can contribute to the family to support to pay the rent or the mortgage. So there are a lot of family pressures on young people to work from quite an early age as well. Many people choose that above the education because of the wish of their family and the pressure from their family too."

Obviously, this interview material plays a prominent role in making viewers aware of an additional constraint imposed on many young Karen which is related to the economic situation of Australian Karen families.

After that, the documentary presents another two interviewees. They can be identified as 'witnesses', another type of informant used widely in documentaries (Bondebjerg, 2014, p.16). The two 'witnesses' include the human resources manager of a plant nursery farm in which a substantial number of Karen work and a teacher in a secondary school. They reflect their own personal experiences of contact with Karen people. Particularly, they describe how good the Karen they know are. The manager, for instance, says that "they always bring their happiness to work and also positive vibes". The teacher adds:

"I've been working with students or the Karen people for about 5 years ... I found that they loved to be in Australia. They try their best to fit in although sometimes I guess it is difficult for them because of the language barrier. But they are so grateful I think to be in Australia. And that is shown in the way that they show respect towards adults, especially myself as a teacher."

This again shows that the documentary maker skilfully uses interview materials which in turn could potentially take charge of the viewers' perception and thereby legitimize the key message of the documentary. At this point, some in the audience would accept what the documentary tries to argue that the social structure and education system of Australia impose serious constraints on the displaced Karen who actually are capable and committed people (good workers, students and community members, for example).

\section{Part 3: living by hope}

In the concluding part, the three main presenters are brought back to the story again. They explain their involvement in their Karen community in Australia such as in cultural events and religious activities. Then they go on to reflect their thoughts of living in their new home. Mayre reveals: "I have improved communication with people. And I understand more about Australian culture and their living style". Lay Wah says: "when I first arrived, I am scared and shy to ask something in English. But now I am confident to speak English". Following the relatively positive reflection (which constitutes balanced representation), the narrator comes to the fore in order to remind audiences that, in his own words, "although young people are more confident in speaking English, there are still many problems in education and employment". After that, a very clear statement picked up from one of the 'expert' interviewees is presented. The co-ordinator of Foundation House explicitly points out:

"Some young people end up leaving the education system and feeling very under-confident and without many options. And I think there need to be greater assistance given to the young people in the education system."

Lay Wah is present once again, this time accompanied by his friend. Lay Wah's friend starts by saying "last year I studied with friends ... pre-apprentice carpentry. We could not find apprenticeship job after this course. We were disappointed. Some went to work at a chicken factory. Here is one of my friends who work there". He then looks at Lay Wah and Lay Wah explains: 
“Umm right, I wasn't accepted for apprenticeship job so I worked at the chicken factory. But [I] didn't stay long because it is not my career in the future. And now I'm doing another course. It is very hard to get a job in Australia."

At the end, the narrator takes charge of the story. He concludes that "while I made this film, the courage of these young people touched me. The challenges in their lives will continue. However, they at the same time maintain their dream for the future". Simultaneously, viewers are offered a series of slow-motion shots showing the very ordinary days of the three young presenters. For instance, Lay Wah is still trying to apply for a job and Delta is walking to school in the morning. According to Murphet (2005, p.63), the distortions of temporality in storytelling, namely slow-motion and accelerated shots as well as freezing frames, can be used to convey "different effective and psychological information about the narrator's (or film-maker's) intention towards the content of the shot". He also suggests that one of the potential meanings of a slow-motion shot is to 'humanise' the subjects or characters in the shot. This last sequence of the documentary therefore tends to underline that the presenters still keep trying and working hard in the new country. This would possibly make some viewers conceive of the young Karen as capable human beings who, despite facing the loss of almost everything in their homeland, never lose their hope for the future. In this instance, viewers are being asked to take the situation of the displaced Karen in the country more seriously. This might be the reason behind the observation that some of the audiences attending the documentary screenings in early 2013 expressed their appreciation of the problems the Karen youth have faced. Some even said that if they had a chance, they would like to contribute in some way to the Karen in the country.

\section{Conclusion: media making, refugee agency and the potential to enhance a better Karen refugee society}

What we clearly see then is that the refugee media producer knows how to take advantage of media production and especially, of nonfiction media representations. Specifically speaking, he knows how to use interview materials, voiceover narration and filming and editing techniques to persuade his target audiences and to serve his project's objective that is to promote the betterment of his Karen society. Such media-making practice reinforces the notion of refugee agency that has gradually been recognised in refugee studies literature in the past few decades (e.g., Watters, 2001; Peisker \& Tilbury, 2003; Marlowe, 2010). The notion of refugee agency suggests that refugees or displaced communities cannot be oversimplified as 'defenceless victims' or 'mute victims', the image or perception often rendered and reproduced in politics, media and also academia, to a certain degree (Lee, 2012, p.265). In many ways, those people have strived to become proactive social actors. Many of them endeavour to master their own lives and also work out ways of achieving their personal and collective ends despite the subordinate status and their social and economic disadvantage in host countries.

Arguably, the agency of the Karen exercised through this Karen documentary among other Karen-made media can play a role in enhancing the capability of the Karen to deal with constraints incurred by migration and displacement. The documentary New Land, New Life is an example of the potential of media making that can become an advocacy tool to raise awareness of the situation of the Karen, notably regarding insufficient support from the government and host society. As highlighted by Chapman (2007, p.57), "[a] good documentary viewing experience can change the way people feel about the issue, as well as presenting them with the information about it". Also, as Abbott (2008, p.145) puts it, in comparing fiction and nonfiction, nonfiction narratives have a unique power to communicate effectively with their audiences. He suggests:

"nonfiction narratives enjoy one attraction that fiction lacks, and that is that they claim to tell a story that is factually true. This is the deep appeal of narratives like history, biography, filmed documentaries, and staged monologues representing a real person in her own words."

Certainly, it can by no means be claimed that all audiences passively consume the documentary or are manipulated by narrative and cinematic devices in the same way. The responses or interpretations of the media audiences may in fact vary from individual to individual. However, the analysis of the refugee documentary text suggests that the documentary project is a timely media outlet that is creatively produced and thus has potential for achieving its aim. 
Last but not least, this article illustrates that media making provides opportunities for the displaced Karen to present their stories through their own voices and in their own words. Refugee-made media tend to serve their needs, tastes and concerns, which are not available in mainstream media in host countries. As maintained by Gifford and Wilding (2013) and Robertson (2014), opportunities for displaced individuals to represent themselves (through virtual spaces in particular) and distribute such representations play a pivotal role in enhancing their sense of being at home in a new country and helping refugees to deal with new and unfamiliar environments. In many studies, when examining issues regarding refugees' integration and settlement, they seem to point out factors such as access to land, accommodation arrangement, employment or access to the labor market and education (Czischke Ljubetic, \& Huisman, 2018; Fasani, Frattini, \& Minale, 2018; Bohnet, \& Schmitz-Pranghe, 2019). While those factors are important, as this paper has showed, opportunities for refugees to engage in digital media production and distribution should also be taken into account, especially by those involved in the policy making. For academics, the role that media creation plays in the lives and integration experiences of refugees or displaced communities in different countries and contexts is worthy of more attention and further research.

\section{References}

Abbott, H. P. (2008). The Cambridge introduction to narrative. Cambridge, England: Cambridge University Press.

Austin, T., \& de Jong, W. (Eds.). (2008). Rethinking documentary: New perspectives, new practices. New York: McGraw Hill/Open University Press.

Bailey, O. G., Georgiou, M., \& Harindranath, R. (Eds). (2007). Transnational lives and the media: Re-imagining diaspora. New York: Palgrave Macmillan.

Banki, S., \& Lang, H. (2008). Protracted displacement on the Thai-Burmese border: The inter-related search for durable solutions. In H. Adelman (Ed.), Protracted displacement in Asia: No place to call home (pp. 59-82). Aldershot, England: Ashgate.

Bodde, R. (2011). Karen refugee ministries: Needs and priorities study. Retrieved from http://www.melbourneanglican.org.au/ServingCommunity

/src/Documents/Karen\%20Refugee\%20Ministries\%20-

$\%$ 20Needs\%20and\%20Priorities\%20Study\%20Feb\%202011.pdf

Bohnet H., \& Schmitz-Pranghe C. (2019). Uganda a role model for refugee integration? Bonn International Center for Conversion. Retrieved from https://www.bicc.de/publications/publicationpage/publication/uganda-arole-model-for-refugee-integration-850/

Bondebjerg, I. (2014). Documentary and cognitive theory: Narrative, emotion and memory. Media and Communication, 2(1), 13-22. Retrieved from http://0search.proquest.com.alpha2.latrobe.edu.au/docview/1545083954?pq-origsite=summon

Chapman, J. (2007). Documentary in practice. Cambridge, England: Polity.

Chapman, J. (2009). Issues in contemporary documentary. Cambridge, England: Polity.

Czischke Ljubetic, D., \& Huisman, C. (2018). Integration through collaborative housing? Dutch starters and refugees forming self-managing communities in Amsterdam. Urban Planning, 3(4), 156-165. doi: https://doi.org/10.17645/up.v3i4.1727

Ellis, J. (2012). Documentary: Witness and self-revelation. Hoboken, NJ: Taylor and Francis.

Fasani, F., Frattini, T., \& Minale, L. (2018). (The struggle for) refugee integration into the labour market: evidence from Europe. IZA Discussion Papers 11333, Institute of Labor Economics (IZA). Retrieved from https://www.econstor.eu/handle/10419/177137

Fuertes, A. (2010). Birds inside a cage: Metaphor for Karen refugees. Social Alternatives, 29(1), 20-24. Retrieved from http://0-search.proquest.com. alpha2.latrobe.edu.au/docview/213963558?accountid=12001

Gifford, S., \& Wilding, R. (2013). Digital escapes? ICTs, settlement and belonging among Karen youth in Melbourne, Australia. Journal of Refugee Studies, 26(4), 558-575. doi: 10.1093/jrs/fet020

Green, G., \& Lockley, E. G. (2012). Communication practices of the Karen in Sheffield: Seeking to navigate their three zones of displacement. Asian Journal of Communication, 22(6), 1-18. doi: 10.1080/01292986.2012.717095 
Harkins, B. (2012). Beyond "temporary shelter": A case study of Karen refugee resettlement in St. Paul, Minnesota. Journal of Immigrant \& Refugee Studies, 10(2), 184-203. doi: 10.1080/15562948.2012.674326

Lee, S. K. (2012). Scattered but connected: Karen refugees' networking in and beyond the Thailand-Burma borderland. Asian and Pacific Migration Journal, 21(2), 263-285. Retrieved from http://0search.proquest.com.alpha2. latrobe.edu.au/docview/1315601411?accountid=12001

Marlowe, J. M. (2010). Beyond the discourse of trauma: Shifting the focus on Sudanese refugees. Journal of Refugee Studies, 23(2), 183-198. doi: 10.1093/jrs/feq013

Matsaganis, M. D., Katz, V. S., \& Ball-Rokeach, S. (2011). Understanding ethnic media: Producers, consumers, and societies. Los Angeles, CA: Sage.

Murphet, J. (2005). Narrative time. In H. E. Fulton (Ed.), Narrative and media (pp. 60-72). Port Melbourne, VIC: Cambridge University Press.

Peisker, V. C., \& Tilbury, F. (2003). “Active” and "passive” resettlement: The influence of support services and refugees' own resources on resettlement style. International Migration, 41(5), 61-91. doi: 10.1111/j.00207985.2003.00261.x

Power, D. V., \& Pratt, R. J. (2012). Karen refugees from Burma: Focus group analysis. International Journal of Migration, Health and Social Care, 8(4), 156-166. doi: 10.1108/17479891211287058

Rangkla, P. (2014). Karen ethno-nationalism and the wrist-tying ceremony along the Thai-Burmese border. Journal of Southeast Asian Studies, 45(1), 74-89. doi: 10.1017/S002246341300060X

Robertson, Z. (2014). Landscapes of affinity: Movement, memory and practices of the imagination amongst resettled Karen refugees in Melbourne, Australia. PhD thesis, Swinburne University of Technology. Retrieved from http://researchbank.swinburne.edu.au/vital/access/manager/Repository/swin:38500

Swe, Y. Y. (2013). Mobility encounter: The narratives of Burmese refugees in Norway. Norwegian Journal of Geography, 67(4), 229-238. doi: 10.1080/00291951.2013.837501

Thawnghmung, A. M. (2012). The "other" Karen in Myanmar: Ethnic minorities and the struggle without arms. Lanham, MD: Lexington Books.

Watters, C. (2001). Emerging paradigms in the mental health care of refugees. Social Science \& Medicine, 52(11), 1709-1718. doi: 10.1016/S0277-9536(00)00284-7 